\title{
Effect of intercropping carrot (Daucus carota L.) with two aromatic plants, coriander (Coriandrum sativum L.) and summer savory (Satureja hortensis L.), on the population density of select carrot pests
}

\author{
Beata Jankowska*, Elżbieta Wojciechowicz-Żytko \\ Department of Plant Protection \\ Faculty of Biotechnology and Horticulture, University of Agriculture in Kraków \\ 29 Listopada 54, 31-425 Kraków, Poland
}

\begin{abstract}
Intercropping, or the use of different aspects of the interaction between organisms in ecosystems, can be classified as an ecological method that limits harmful human interference in the environment, especially the consumption of chemicals. The impact of intercropping carrot with coriander Coriandrum sativum L. and summer savory Satureja hortensis L. on the occurrence of select carrot pests was estimated in the years 2010-2011. Intercropping had a significant effect on the decrease of the number of roots damaged by carrot rust fly Psila rosae. During harvest, the least number of damaged roots was observed in combination with summer savory S. hortensis L. The number of carrot psyllid Trioza viridula Zett. and aphids on carrot leaves and roots damaged by nematodes was significantly lower on plots where carrot was intercropped. Intercropping both herbs had a positive influence on the number of beneficial insects. In all of the years of the study, the highest number of Coccinellidae and Syrphidae were observed on plots where carrot was intercropped with coriander.
\end{abstract}

Key words: carrot protection, mixed cropping, non-chemical methods, pests

\section{INTRODUCTION}

Carrots have been grown for many years in different regions of Poland and have become a natural habitat for many phytophagous animals (Szwejda and Wrzodak 2007). Pest occurrence is a severe problem in vegetable cultivation. There is growing public concern about the non-target effects of pesticides on humans and other organisms, and many pests have evolved resistance to some of the most commonly-used pesticides. Monoculture farms do not provide the resources for natural enemies to provide natural control services (Rusch et al. 2010) and intensive cropping of carrot and indiscriminate use of pesticides are annihilating natural enemies. Together, these factors have led to increasing interest in non-chemical, ecologicallysound ways to manage pests. One pest-management alternative is the diversification of agricultural fields by establishing "polycultures" (mixed cropping, intercropping, undersowing, etc.) that include one or more different crop varieties or species within the same field, to more-closely match the higher species richness typical of natural systems (Wiech and Kałmuk 2005, Jankowska et al. 2009, Wnuk and Wojciechowicz-Żytko 2010).

\footnotetext{
*Corresponding author.

Tel.: +48 126625310 ;

e-mail: jankowskab@ogr.ar.krakow.pl (B. Jankowska).
} 
Several studies have demonstrated that the diversification of the agroecosystem may reduce insect pest infestation using the strategy of companion planting. Intercropping, using different aspects of the interaction between organisms in ecosystems, may be classified as a pro-ecological method, limiting harmful human interference in the environment, especially the consumption of chemicals. Diversity in landscape structures influences ecosystem services provided by insects by supporting generalist predators and parasitoids (Altieri and Letourneau 1982, Hurej et al. 1998, Altieri 1999, Jankowska 2007, Wiech et al. 2009, Jankowska 2010, 2012). The association between intercropped components has become a point of interest for many researchers studying environmental resource management with respect to productivity and economic indicators (Neto et al. 2010). Foraging adults of phytophagous insects are attracted by host-plant volatiles and supposedly repelled by volatiles from non-host plants. The hostplant-finding behaviour of insects may be disrupted by the close comparison of two plant species. In research on crop species diversification's impact on the presence of 198 pest species, a decrease in their number was confirmed in $59 \%$ of cases (Risch et al. 1983). Andow (1991) analysed 209 studies involving 287 pest species. Compared with monocultures, the population of pest insects was lower in 52\% of them (149 species). The mutual tolerance of selected species and their beneficial impact on plant health are important in choosing the right partner for intercropping. Plants with aromatic qualities contain volatile oils that may interfere with host plant location, feeding, distribution and mating, resulting in decreased pest abundance (Finch et al. 2003, Lu et al. 2007). Therefore, the aim of the investigation was to determine the influence of intercropping carrot with Coriandrum sativum and Satureja hortensis on the occurrence of select carrot pests.

\section{MATERIAL AND METHODS}

The research was carried out on a farm situated in Jelcza (in 2010) and in the Experimental Station in Mydlniki (in 2011) near Krakow (Poland). The combinations of the experiment included three objects: a homogenous crop of carrot, carrot intercropped with coriander Coriandrum sativum L. and carrot intercropped with summer savory Satureja hortensis L. In the first year of the study, the late cultivar 'Joba', primarily used for processing, was sown, whereas in the second year the suitability of early cultivar 'Amsterdamska' for intercropping was tested.

For the experiment, $8.4 \mathrm{~m}^{2}$ plots $(2.10 \mathrm{~m}$ long and $4 \mathrm{~m}$ wide) were prepared for each combination. Carrots and herbs were sown manually (on 24 April in 2010 and 20 April in 2011) in rows spaced $35 \mathrm{~cm}$ apart. On plots with intercropping, the herbs were planted in the extreme rows. The plants were thinned to regulate their density in the rows in mid-July. No chemical treatments were applied to the plots and weeds were removed mechanically. Carrot plants in each plot from three $40 \mathrm{~cm}$ sections (three replications) from the middle rows were inspected every week, and pests (carrot psyllid Trioza viridula Zett., Lygus sp., aphids) feeding on the aboveground parts of carrot were counted. The larvae and pupae of Syrphidae and the larvae and beetles of Coccinellidae were counted as well for all of the plants on the plots. The percentage of plants damaged by the carrot rust fly Psila rosae (F), root aphids Pemphigus phenax B\&B, haworth carrot aphid Dysaphis crataegi Kalt and nematodes was assessed once in July (during the thinning of carrot) and after harvest on the roots. The roots were harvested on 10 September 2010 and 22 September 2011. The Duncan multiple test $(p=0.05)$ was used for the statistical analysis of the results.

\section{RESULTS AND DISCUSSION}

A significant difference in damage between the control and the intercrop treatments was found in all of the years of the study. Three species of aphids were found on the leaves: willow carrot aphid Cavariella aegopodii (Scop.), Semiaphis dauci (Fabr.) and the bean aphid Aphis fabae L. The identification of aphids can be found in Cichocka (1999). The most numerous were S. dauci in 2010 and C. aegopodi in 2011. Clear differences were noted from the beginning of aphid population development. A significantly higher number of aphids was recorded on the plot where carrot was sown as a homogenous crop (Tabs 1,2). Several factors determine searching and choosing a host plant by insects. Finding a host plant may be more difficult when it grows between non-host plants. Finch and Collier (2000) have discussed how both chemical and visual stimuli affect the behaviour of insects during the period prior to accepting a plant as a suitable host (theory based on "appropriate / inappropriate landings"). Tukahirwa and Coaker (1982) point out the role of the visual factor in finding a host plant. They claim that in a homogenous crop the soil of the intercrop 
Table 1. The influence of intercropping on the occurrence of select pests on carrot in 2010

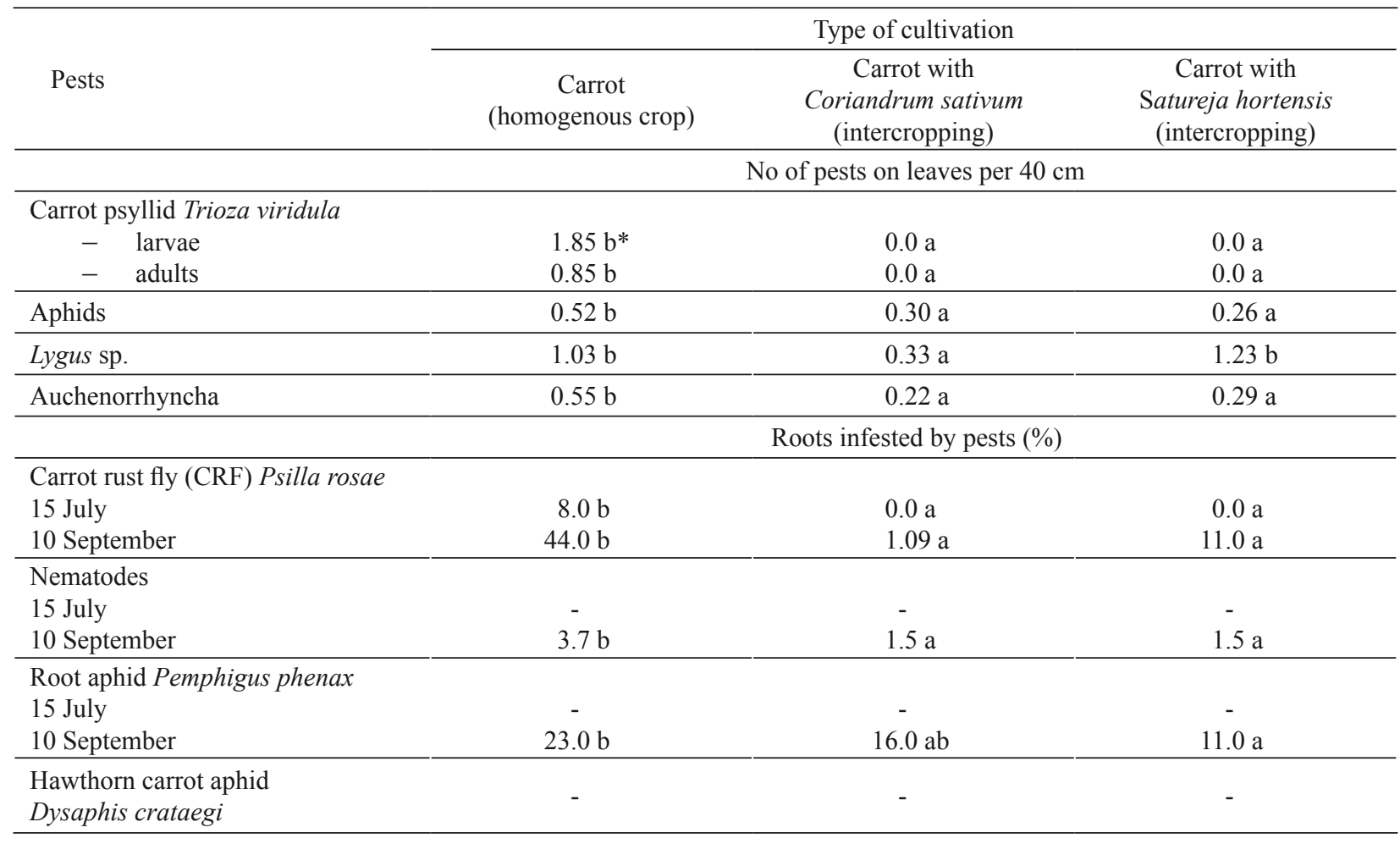

*Means followed by the same letter within rows are not significantly different $(p=0.05)$

contrasts with the host plant, which makes it more on carrot leaves as well. These species cause visible and attractive for the aphids flying in.

Larvae and adults of carrot psyllid Trioza viridula Zett. (syn. T. apicalis Först.) were noted significant economic losses in Poland (Łuczak 2007, Szwejda and Wrzodak 2007). In both years of observation, the number of larvae and adults

Table 2. The influence of intercropping on the occurrence of select pests on carrot in 2011

\begin{tabular}{|c|c|c|c|}
\hline \multirow[b]{2}{*}{ Pests } & \multicolumn{3}{|c|}{ Type of cultivation } \\
\hline & $\begin{array}{c}\text { Carrot } \\
\text { (homogenous crop) }\end{array}$ & $\begin{array}{l}\text { Carrot with } \\
\text { Coriandrum sativum } \\
\text { (intercropping) }\end{array}$ & $\begin{array}{l}\text { Carrot with } \\
\text { Satureja hortensis } \\
\text { (intercropping) }\end{array}$ \\
\hline & \multicolumn{3}{|c|}{ No of pests on leaves per $40 \mathrm{~cm}$} \\
\hline \multicolumn{4}{|l|}{ Carrot psyllid Trioza viridula } \\
\hline - larvae & $2.3 \mathrm{~b}^{*}$ & $0.0 \mathrm{a}$ & $0.2 \mathrm{a}$ \\
\hline- adults & $1.2 \mathrm{~b}$ & $0.1 \mathrm{a}$ & $0.0 \mathrm{a}$ \\
\hline Aphids & $1.4 \mathrm{~b}$ & $0.6 \mathrm{a}$ & $0.7 \mathrm{a}$ \\
\hline Lygus sp. & $1.2 \mathrm{~b}$ & $0.5 \mathrm{ab}$ & $0.9 \mathrm{~b}$ \\
\hline Auchenorrhyncha & $0.5 \mathrm{~b}$ & $0.1 \mathrm{a}$ & $0.3 \mathrm{ab}$ \\
\hline & \multicolumn{3}{|c|}{ Roots infested by pests (\%) } \\
\hline $\begin{array}{l}\text { Carrot rust fly (CRF) Psilla rosae } \\
14 \text { July } \\
28 \text { September }\end{array}$ & $\begin{array}{l}0.5 \mathrm{~b} \\
6.0 \mathrm{~b}\end{array}$ & $\begin{array}{l}0.0 \mathrm{a} \\
2.0 \mathrm{a}\end{array}$ & $\begin{array}{l}0.0 \mathrm{a} \\
1.2 \mathrm{a}\end{array}$ \\
\hline $\begin{array}{l}\text { Nematodes } \\
14 \text { July } \\
28 \text { September }\end{array}$ & $20.0 \mathrm{c}$ & $14.0 \mathrm{bc}$ & $5.7 \mathrm{a}$ \\
\hline $\begin{array}{l}\text { Root aphid Pemphigus phenax } \\
\text { 14 July } \\
\text { 28 September }\end{array}$ & - & - & $\begin{array}{c}- \\
0.3 \mathrm{a}\end{array}$ \\
\hline $\begin{array}{l}\text { Hawthorn carrot aphid } \\
\text { Dysaphis crataegi }\end{array}$ & $12.3 \mathrm{~b}$ & $4.2 \mathrm{a}$ & $5.3 \mathrm{a}$ \\
\hline
\end{tabular}

*Explanations: see Table 1 
Table 3. Occurrence of select beneficial insects on carrot according to the type of cultivation (2010-2011)

\begin{tabular}{|c|c|c|c|c|}
\hline \multirow[b]{2}{*}{ Pests } & & \multicolumn{3}{|c|}{ Type of cultivation } \\
\hline & & $\begin{array}{c}\text { Carrot } \\
\text { (homogenous crop) }\end{array}$ & $\begin{array}{c}\text { Carrot with } \\
\text { Coriandrum sativum } \\
\text { (intercropping) }\end{array}$ & $\begin{array}{c}\text { Carrot with } \\
\text { Satureja hortensis } \\
\text { (intercropping) }\end{array}$ \\
\hline & & \multicolumn{3}{|c|}{ No of pests on leaves per $40 \mathrm{~cm}$} \\
\hline \multirow{5}{*}{2010} & Coccinellidae & & & \\
\hline & - larvae & $0.28 *$ & 0.44 & 0.30 \\
\hline & - $\quad$ adults & 0.30 & 0.48 & 0.41 \\
\hline & - total & $0.58 \mathrm{a}$ & $0.92 \mathrm{c}$ & $0.71 \mathrm{~b}$ \\
\hline & Syrphidae (larvae and pupae) & $0.22 \mathrm{a}$ & $0.33 \mathrm{~b}$ & $0.33 \mathrm{~b}$ \\
\hline \multirow{5}{*}{2011} & Coccinellidae & & & \\
\hline & - larvae & 0.16 & 0.56 & 0.33 \\
\hline & - $\quad$ adults & 0.30 & 1.03 & 0.63 \\
\hline & - total & $0.46 \mathrm{a}$ & $1.59 \mathrm{c}$ & $0.96 \mathrm{~b}$ \\
\hline & Syrphidae (larvae and pupae) & $0.38 \mathrm{a}$ & $1.13 \mathrm{c}$ & $0.91 \mathrm{~b}$ \\
\hline
\end{tabular}

*Explanations: see Table 1

of carrot psyllid on carrot plants grown on plots with a homogenous crop was significantly higher compared with the intercropped carrot (Tabs 1, 2). In 2010, the plants intercropped with coriander and summer savory were free from psyllids until the end of the season (Tab. 1). The intercropping of carrots with garden beans (Luik et al. 2000) and with Tagetes and Calendula (Jankowska et al. 2012) significantly disoriented pests and decreased the damage of carrots by Trioza viridula and Psila rosae. Adults of Auchenorrhyncha and Lygus sp. were noted on carrot leaves. There was no positive impact of intercropping on the occurrence of these insects (Tabs 1,2). These are highly polyphagous and mobile pests, and they can exploit various field crops and weed hosts for their population development and maintenance.

During the study, carrot roots were infested by carrot rust fly (CRF) Psila rosae (F.), root aphid Pemphigus phenax $\mathrm{B} \& \mathrm{~B}$, hawthorn carrot aphid Dysaphis crataegi Kalt. (only in 2011) and nematodes. The carrot rust fly (CRF) Psila rosae (F.) is a very important pest in the temperate regions of the world. It is an oligophagous pest insect whose larvae feed on the roots of a wide range of cultivated (more than a 100 plant species exclusively belonging to the family Apiaceae e.g., carrot, celeriac, and parsley) and wild umbelliferous species (Ellis et al. 1993). The female flies perform exploratory runs over the leaves of potential host plants and, when stimulated, move down the stem axis to deposit eggs in the soil near the plant's base. Olfactory stimuli from the carrot plant seems to be most important in the pest's initial orientation to the host. CRF and other carrot pests are attracted to chlorogenic acid (Cole 1985, Cole et al. 1988). Semiochemicals (e.g. propenylbenzenes, furanocoumarins, polyacetylenes) in the surface wax of carrot leaves have been shown to stimulate CRF oviposition (Degen et al. 1999a, b). Therefore, even the attractiveness of carrot cultivars for pests varies (Michalik and Wiech 2000, Luczak 2007). In all of the years of research, the percentage of roots damaged by carrot rust fly was significantly higher in the control plot (homogenous crop). A smaller number of damaged crops was recorded on plots where carrot was intercropped with summery savory (Tabs 1, 2). The host-plant finding behaviour of insects may be disrupted by the close comparison of two plant species. Intercropping seems to have a large effect on insects that oviposition in the soil, such as the carrot fly (Rämert and Ekbom 1996, Rämert 1996). The proximity of plants that are non-hosts may mask the scent of host plants, which hampers their finding.

Many authors have noted that intercropping carrots with a cover crop has been found to effectively reduce attack by the carrot fly and carrot damage (Uwah and Coaker 1984, Rämert 1993, Rämert and Ekbom 1996, Luik et al. 2000, Theunissen and Schelling 2000, Jankowska et al. 2012). In all of the years of research, the percentage of roots damaged by root aphid Pemphigus phenax $\mathrm{B} \& \mathrm{~B}$ was higher in the control plot (homogenous crop) (Tabs 1, 2), but in 2010 this difference was significant only in relation to intercropping with $S$. hortensis (Tabs 1,2). A significantly highest number of roots infested by hawthorn carrot aphid Dysaphis crataegi (in 2011) was recorded in plots with carrot sown as a homogenous crop (Tabs 1,2). A distortion of root structure, a typical nematode damage symptom, was observed in 2010 and 2011. Carrots affected by nematodes often exhibit 
a forking of the taproot, stubbing of the roots, and unsightly galls on the taproot and secondary roots. A significantly highest number of damaged roots was recorded on plots with carrot sown as a homogenous crop. A smaller number of damaged roots was recorded on plots with carrot intercropped with summer savory in 2011 (Tabs 1, 2).

During the research, a seven-spotted lady beetle (Coccinella septempunctata L.), two-spotted lady beetles (Adalia bipunctata L.), the multi-coloured Asian lady beetle (Harmonia axyridis Pall.) and Syrphidae were observed. The most numerous species from Coccinellidae was C. septempunctata. Ladybird larvae and beetles (Lipok 1993) and syrphid larvae are often effective in destroying aphids. In all of the study years, the number of beneficial insects was highest on plots where carrot was intercropped with coriander (Tab. 3). The use of plants to provide nectar and pollen resources to natural enemies through habitat management is a growing focus of conservation biological control. Plants used for intercropping with carrot were attractive for insects including Syrphidae. A lot of hoverflies were especially observed on coriander flowers. The increasing number of useful organisms in diverse agroecosystems has also been highlighted by Root (1973). Diversity in landscape structures influences ecosystem services provided by insects by supporting generalist predators and parasitoids (Altieri and Letourneau 1982, Hurej et al. 1998, Altieri 1999, Jankowska 2007, Wiech et al. 2009, Jankowska 2010, 2012).

\section{CONCLUSIONS}

1. Intercropping had a significant effect on the decrease in the number of roots damaged by carrot rust fly Psila rosae. During harvest the least number of damaged roots were observed in combination with summer savory $S$. hortensis L.

2. The number of carrot psyllid T. viridula Zett. and aphids on carrot leaves and roots damaged by nematodes was significantly lower on plots where carrot was intercropped.

3. Intercropping both herbs positively influenced the number of beneficial insects. In all years the highest number of Coccinellidae and Syrphidae was observed on plots where carrot was intercropped with coriander.

\section{FUNDING}

This research was supported by the Ministry of Science and Higher Education of Poland as part of the statutory activities of the Department of Plant Protection of the University of Agriculture, DS$3500 / \mathrm{WBiO} /$.

\section{AUTHOR CONTRIBUTIONS}

Both authors contributed equally to this work. B.J. and E.W.Z. designed and performed the experiments, analysed the data and wrote the paper.

\section{CONFLICT OF INTEREST}

Authors declare no conflict of interest.

\section{REFERENCES}

Altieri M.A., 1999. The ecological role of biodiversity in agroecosystems. Agric. Ecos. Environ. 74: 19-31.

Altieri M.A., Letourneau D.K., 1982. Vegetation management and biological control in agroecosystems. Crop Prot. 1(4): 405-430.

ANDow D.A., 1991. Vegetational diversity and arthropod population response. Ann. Rev. Entomol. 36: 561568.

CichockA E., 1999. Jak rozpoznawać mszyce na warzywach gruntowych. In: "Diagnostyka szkodników roślin i ich wrogów naturalnych". J. Boczek (ed.), V III. SGGW, Warszawa.

Cole R.A., 1985. Relationship between the concentration of chlorogenic acid in carrot roots and the incidence of carrot fly larval damage. Ann. Appl. Biol. 106: 211-217.

Cole R.A., Phelps K., Ellis P.R., 1988. Further studies relating chlorogenic acid concentration in carrots to carrot fly damage. Ann. Appl. Biol. 112: 13-18.

Degen T., Buser H.R., Städler E., 1999a. Pattern of oviposition stimulants for carrot fly in leaves of various host plants. J. Chem. Ecol. 25(1): 66-87.

Degen T., Poppy G., Städler E., 1999b. Extracting oviposition stimulants for carrot fly from host-plant leaves. J. Chemical Ecol. 25(1): 88-104.

Ellis P.R., Hardman J.A., Crowther T.C., Saw P.L, 1993. Exploitation of the resistance to carrot fly in the wild carrot species Daucus capillifolius. Ann. Appl. Biol. 122: 79-91.

Finch S., Collier R.H., 2000. Host-plant selection by insects-a theory based on "appropriate/inappropriate landings" by pest insects of cruciferous plants. Ent. Exp. Appl. 96: 91-102.

Finch S., Billiad H., Collier R.H., 2003. Companion planting - do aromatic plants disrupt host - plant finding by the cabbage root fly and the onion fly more effectively than non-aromatic plants. Ent. Exp. Appl. 109: 183-195.

Hurej M., Król J., Twardowski J., 1998. Attraction of aphid predators by cultivated and weedy strip. Aphids and Other Homopterous Insects 6: 117-124.

JANKOWSKA B., 2007. Impact of intercropping white cabbage with Pot Marigold (Calendula officinalis L.) 
and French Marigold (Tagetes patula nana) on the occurrence of cabbage aphid (Brevicoryne brassicae L.), its parasitoid Diaeretiella rapae M'Intosh and predatory Syrphidae. Aphids and Other Hemipterous Insects 13: 199-209.

JANKOWSKA B., 2010. Effect of intercropping white cabbage with French Marigold (Tagetes patula nana) and Pot Marigold (Calendula officinalis) on population density of diamondbath moth DBM (Plutella xylostella) and it's parasitoid complex. Veg. Crops Res. Bull. 73: 107-117.

JANKOWSKA B., 2012. Wpływ wybranych niechemicznych sposobów ochrony warzyw kapustowatych na szkodliwą i pożyteczną entomofaunę. Zesz. Nauk. UR w Krakowie, ser. Rozprawy 491, zesz. 368.

Jankowska B., Poniedzialek M., Jędrszczyk E., 2009. Effect of intercropping white cabbage with French Marigold (Tagetes patula nana) and Pot Marigold (Calendula officinalis L.) on the plants colonization by herbivorous pest insects. Folia Hort. 21(1): 95-103.

Jankowska B., Jędrszczyk E., Poniedzialek M., 2012. Effect of intercropping carrot (Daucus carota L.) with french marigold (Tagetes patula nana L.) and pot marigold (Calendula officinalis L.) on occurrence of some pests and the quality of carrot yield. Acta Agrobot. 65(4): 133-138.

LipOK J., 1993. Natural reduction of willow carrot aphids by Coccinellidae on a carrot crop. Folia Hort. 5(2): 87-93.

Lu W., Hou M.L., Wen J.H., Li J.W., 2007. Effects of plant volatiles on herbivorous insects. Plant Prot. 33: $7-11$.

Luik A., Heidemaa M., Viidalepp V., 2000. The influence of intercropping and saw dust mulching on carrot yeld and entomofauna. Transactions of the Estonian Agricultural University, Agron. 208: 115-120.

ŁUCZAK I., 2007. Occurrence of carrot psyllid (Trioza viridula Zett.) on various carrot and parsley cultivars. Prog. Plant Protection / Post. Ochr. Roślin 47(1): 310313.

Michalik B., Wiech K., 2000. Differences in the resistance of carrot lines and cultivars to carrot fly [Psila rosae (Fabr.)] attack. Folia Hort. 12(2): 43-51.

Neto F.B., Gomes E.G., Araujo R.R., Oliveira E.Q., Sousa Nunes G.H., Grangeiro L.C., Silveira Borges Azevedo C.M., 2010. Evaluation of yield advantage indexes in carrot-lettuce intercropping systems. J. Appl. Ecol. 39(3): 416-426.

RÄMERT B., 1993. Mulching with grass and bark and intercropping with Medicago littoralis against carrot rust fly (Psila rosae). Biol. Agric. Hort. 9: 125-135.

RÄMERT B., 1996. Intercropping as a strategy for reducing damage to carrots caused by the carrot fly, Psila rosae. Biol. Agric. Hort. 13: 359-369.
RÄмеRT B., Еквом B., 1996. Intercropping as a management strategy against carrot rust fly (Diptera: Psilidae): A test of enemies and resource concentration hypothesis. Environ. Entomol. 25(5): 1092-1100.

Risch S.J., Andow D.A., Altieri M.A., 1983. Agroecosystems diversity and pest control: data, tentative conclusions and new research direction. Environ. Entomol. 12: 625-629.

Rоот R.B., 1973. Organization of plant-arthropod association in simple and diverse habitats: the fauna of collards (Brassica oleracea). Ecological Monograph. 43: 95-125.

Rusch A., Valantin-Morison M., Sarthou J.P., RogerEstrade J., 2010. Biological control of insect pests in agroecosystems: effects of crop management, farming systems, and semi-natural habitats at the landscape scale: A review. Adv. Agron. 109: 219-259.

SzweJdA J., WRzodAK R., 2007. Phytophagous entomofauna occurring on carrot and plant protection methods. Veg. Crops Res. Bull. 67: 95-102.

Theunissen J., Schelling G., 2000. Undersowing carrots with clover: suppression of carrot rust fly (Psila rosae) and cavity spot (Phytium spp.) infestation. Biol. Agric. Hortic. 18: 67-76.

Tukahirwa E.M., Coaker T.H., 1982. Effect of mixed cropping on some insect pest of brassicas; reduced Brevicoryne brassicae infestations and influences on epigeal predators and the disturbance of oviposition behaviour in Delia brassicae. Ent. Exp. Appl. 32: 129-140.

UvAh I.I.I., COAKER T.H., 1984. Effect of mixed cropping on some insect pests of carrots and onions. Entomol. Exp. Appl. 36(2): 159-167.

Wiech K., KaŁmuk J., 2005. Uprawy współrzędne sposobem na urozmaicenie agrocenoz i zmniejszenie użycia pestycydów. In: „Ochrona środowiska naturalnego w XXI wieku - nowe wyzwania i zagrożenia". K. Wiech, H. Kołoczek, P. Kaszycki (eds), TEXT, Kraków.

Wiech K., WNuk A., Wojciechowicz-Ż̀tKo E., JANKOWSKA B., 2009. Wpływ infrastruktury ekologicznej na agrofagi i organizmy antagonistyczne w uprawach warzyw. Prog. Plant Prot. / Post. Ochr. Roślin 49(3): 1124-1132.

Wnuk A., Wosciechowicz-Żytкo E., 2010. The influence of intercropping broad bean with phacelia on the occurrence of weevils (Sitona spp.) and broad bean beetles (Bruchus rufimanus Boh.). Folia Hort. 22(2): 33-37.

Received August 26, 2015; accepted November 29, 2015 